\title{
Growing food, growing a movement: How structural racism affects immigrant farmers
}

Review by Claire Hutkins Seda, Migrant Clinicians Network*

Review of The New American Farmer: Immigration, Race, and the Struggle for Sustainability, by Laura-Anne Minkoff-Zern. (2019). MIT Press. Available as paperback and eBook; 216 pages. Publisher's website:

https://mitpress.mit.edu/books/new-american-farmer

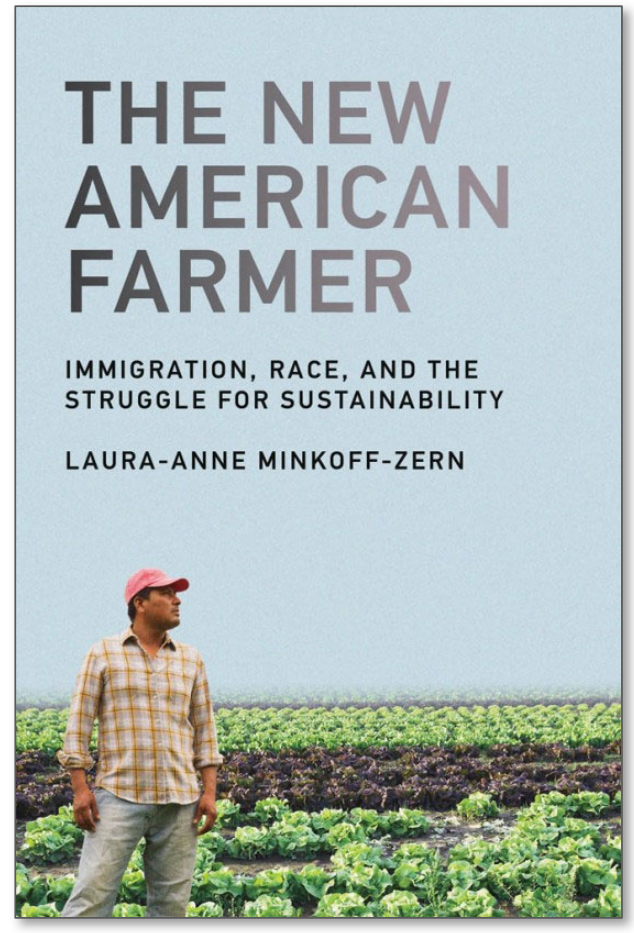

Submitted June 25, 2020 / Published online September 21, 2020

Citation: Seda, C. H. (2020). Growing food, growing a movement: How structural racism affects immigrant farmers [Book review]. Journal of Agriculture, Food Systems, and Community Development, 9(4), 347-349. https://doi.org/10.5304/jafscd.2020.094.038

Copyright (C) 2020 by the Author. Published by the Lyson Center for Civic Agriculture and Food Systems. Open access under CC-BY license.

$\mathrm{M}$ ost U.S. farmers and farm owners are white, while most farmworkers are Latinx immigrants. This timely book uncoils the history, institutions, and politics that racialize farming in America and the growing number of immigrant farmers-primarily small-scale and Mexican—who have climbed the agricultural ladder despite the

* Claire Hutkins Seda is a writer focused on social and environmental issues. She is senior writer and editor for Migrant Clinicians Network, a national nonprofit focused on health justice that creates practical solutions at the intersection of vulnerability, migration, and health. She can be reached at the Migrant Clinicians Network; P.O. Box 164285; Austin, TX 78716 USA; cseda@migrantclinician.org crushing barriers they face. Author Laura-Anne Minkoff-Zern deftly spells out the social, political, and cultural influences that built racism and antiimmigrant practices directly into the structure of American agriculture. She then enriches the picture with the stories of 70 interviewed immigrant farmers who operate within this structure; excerpts from her interviews are spotlighted throughout the book. Additional interviews with agricultural support and outreach programs emphasize how immigrant farmers are often excluded from start-up capital, land access, and farmers market access. The storytelling element, paired with Minkoff-Zern's first-person perspectives and reactions, enliven 
each chapter and extricate the book from a purely scholarly work into an engaging read on immigration, race, and agriculture.

The book starts off with a snapshot of immigrant farmers in America, followed by a short preface on how Minkoff-Zern found the farmers she interviewed, from California's Central Coast, the Northern Neck of Virginia, the "black dirt" region of New York's Hudson Valley, northwestern and central Washington State, and southeastern Minnesota. The second chapter, "Sharecroppers, Braceros, and 'Illegals': Racializing the Agricultural Ladder," explores the links in the chain from the unfulfilled promise of " 40 acres and mule" after emancipation, to the Bracero program, "Operation Wetback" and deportation, and their legacies evident in "the structural conditions encouraging lowpaid immigrant labor and criminalizing the people who perform it" (p. 43). She then shows how structural racism perpetuates itself through poor census counts, as many immigrant farmers, perhaps due to low literacy and English proficiency or fear of exposing immigration status, decline to complete the census form, which in turn affects policy priorities and funding.

Institutions designed to support farmers routinely ignore Latinx immigrant farmers, as reported in the third chapter. For example, the U.S. Department of Agriculture (USDA) was sued in the 2000s for structurally discriminating against farmers of color, and it continues to lack consistent methods for interaction with and outreach to immigrant farmers. Minkoff-Zern found that farmer support networks and groups like the Farm Service Agency often did not have staff that spoke Spanish. Latinx immigrant farmers, for their part, had few records of their farming practices-which is critical to applying for various programs and services. English language proficiency and literacy rates varied among farmers, erecting another potential barrier to them working with support organizations and completing paperwork.

Finally, many of the support programs, including from the USDA, are built with large-scale farmers' needs in mind. The mismatch in support mechanisms continues when farm products are ready for sale. Minkoff-Zern argues that small-scale immigrant farmers are "de-prioritized" in the grow- ing farmers market movement, shutting them out of much-needed market mechanisms like direct-toconsumer sales (p. 86).

In the fifth chapter, "Food, Identity, and Agricultural Practice: Re-creating Home through the Family Farm," the farmers' stories at last dominate the conversation instead of augmenting it, as Minkoff-Zern explores why, in the face of extreme racial exclusions, farmers push forward. The stories of farmers wishing to create a recuerdo, or memory, of their former agricultural lifestyles in Mexico-providing healthy food for their families and communities, and reclaiming a sense of self and place after migration — enriched the picture of small-scale immigrant farming in America today. However, Minkoff-Zern notes that not all the farmers she interviewed fit the tidy and idyllic small-scale, diversified, low-chemical-input family farm label; some of the farmers she interviewed, mostly orchardists in Washington state, operated large industrial operations. In the sixth chapter, entitled "Shifting the Means of Production," she also notes that those who needed to hire workers outside the family struggled with the same financial restraints that larger farms do, and even family labor "does not imply an inherently better or more equitable labor system, and by no means ensures labor justice on the farm" (p. 152).

It is in the sixth chapter that Minkoff-Zern finally approaches the legacy of colonialism, international development, food policy, and globalism that forced many of these farmers off their home farms and induced them to migrate to the U.S. in the first place. This is important context that felt missing from the first half of the book. She goes on to frame a conversation about generations-long Mexican small-scale farmers' resistance to dispossession, farmers' love of farming, and their value of independence over profit.

The seventh and final chapter of the book encourages better literacy around the social and political factors that underpin agriculture in order to address the structural racism that confronts immigrant farmers, noting that "Only by looking closely at the differences in lived experiences between racialized groups of food producers, and appreciating both their race- and citizenship-based obstacles as well as their unique offerings and 
skills, can we begin to form a new theory of agrarian change" (p. 168). The farmer profiles provide a useful blueprint for agriculture institutions to pinpoint and begin to dismantle racial disparities.

At times, this book felt like a companion reader to the news. In the spring of 2020, COVID19 pummeled rural America, with massive outbreaks at farms and meatpacking houses that primarily employ low-wage immigrant Latinx workers. Contradictorily, farmworkers were designated as "essential" workers, providing services that America cannot go without, while toiling in an exploitative system that cannot or will not provide the health and safety measures necessary to keep them safe on the job.

Simultaneously, beginning in May 2020, Black Lives Matter protests erupted in cities and towns across the U.S. in response to the killing of George Floyd by police in Minneapolis. The killing and the protests in response held up a mirror up for Americans, exposing the deep-seated racism embedded within our most basic systems. This book provides a useful backdrop for these headlines, for aca- demics and agriculture advocates alike, describing how our agricultural systems came to be and how such basic structures rigidly maintain hierarchies of class, race, and citizenship.

The book also exposes the barriers that immigrant farmworkers (not just farmers) face, including fear of exposing immigration status, deep poverty, and cultural and linguistic barriers. These help explain why, amid the coronavirus pandemic, farmworker health needs are not being met by regulatory systems, and how their ability to advocate for their health is stifled. The farmers profiled in this book illustrate that, contrary to the dominant story of agriculture and in spite of numerous barriers, some immigrant farmers are disrupting the agricultural norm, challenging its racist and classist underpinnings. Their vivid stories unleash a vision of America where racist structures are superseded, and where Latinx farmers' hard work paves the way for a new, more equitable and sustainable agricultural system, which-as evidenced from current events—is much needed. 